\title{
The Effect of Project Based Learning on Seventh Grade Students' Academic Achievement ${ }^{1}$
}

\section{Oktay Kızkapan}

Erciyes University, Graduate School of Educational Sciences, PhD Student, Turkey, okizkapan@gmail.com

Oktay Bektaş

Asst. Prof., Erciyes University, Faculty of Education, Elementary Science Education Department, Turkey, obektas@erciyes.edu.tr

The purpose of this study is to investigate whether there is a significant effect of project based learning approach on seventh grade students' academic achievement in the structure and properties of matter. In the study, according to the characteristics of quantitative research methods, pretest-posttest control group quasi-experimental design was used to test the effect of project-based learning and traditional methods on seventh grade students' academic achievement. Convenience sampling was preferred and 38 students participated in this study. The structure and properties of matter achievement test, lesson plans, and observation checklist were used as data collection instruments. In order to analyze the data obtained from the structure and properties of matter achievement test, independent samples t-test was performed. Based on the results, there is no significant difference between the experimental and control groups' scores which is obtained from their "Achievement test" post-test performance. Discussions based on literature were carried out and suggestions were performed as pre-activities based on project based learning should be performed for the adaptation of students and teachers before treatment.

Key Words: science education, project based learning, academic achievement, particulate nature of matter, quasi experimental design

\section{INTRODUCTION}

Science education has begun to see important constructivism in recent years to create effective teaching/learning strategies. Constructivism expects learners to construct and interpret their new knowledge rather than memorization. Hence, constructivism has been an important approach and established a significant consideration in science education

\footnotetext{
${ }^{1}$ This study was produced from the data of master thesis.

URL: http://www.e-iji.net/dosyalar/iji_2017_1_3.pdf

DOI: $10.12973 / \mathrm{iji} .2017 .1013 \mathrm{a}$
} 
in recent years (Matthews, 1993; Taber, 2008). Constructivist teaching strategies have been started to be used in science classes since students are tried to be active in the class. Researchers have asserted that these strategies remove students' misconceptions and promote meaningful learning (Liang \& Gabel, 2005). There are many constructivist teaching strategies used in the science classes such as project based learning (Filippatou \& Kaldi, 2010), 5E learning cycle model (Cavallo, McNeely, \& Marek, 2003), and inquiry based approaches (Alozie, Moje, \& Krajcik, 2010).

Project Based Learning (PBL) is one of the constructivist teaching strategies and is getting more and more common in science education (Frank \& Barzilai, 2004). PBL enables students to solve the problems by active participation (Doppelt, 2003; Krajcik, Blumenfeld, Marx, \& Soloway, 1994). In PBL, students work collaboratively with others and reflect on what have been learned. Moreover, students can become active in search and decision making processes by improving their practical thinking skills (Harris, 2002; McGrath, 2002; Solomon, 2003). In addition, PBL develops scientific process skills of students. Hence, students who advanced the scientific process skills produce solutions to their scientific problems by asking questions, discussing ideas, making observations and predictions, doing experiments, collecting and analyzing data, and drawing conclusions (Blumenfeld, Soloway, Marx, Krajcik, Guzdial, \& Palincsar, 1991; Westwood, 2006). In fact, in PBL, students collaborate with each other and take their responsibilities as members of a team. Besides, students recognize similarities between what they are learning and what is going on outside the school (Preuss, 2002). Moreover, PBL improves students' metacognitive skills, thus; they make successful plans, and evaluate their solutions (Blumenfeld et al., 1991). Finally, PBL contributes to students' academic achievement by creating a more equal learning environment (Solomon, 2003).

PBL does not have a rigid lesson plan and students determine spectacular path for their learning objectives. Thus, PBL allows students to investigate deeply (Helm \& Katz, 2011). Project works are assigned to individual or to group of students. Then, project work starts with the selection of a particular topic by the learners with the scaffolding of the teacher. The topic is generally a problem that can be solved by the student with an experiment or observation (Bell, 2010). Project works bring opportunities for students to promote their achievement. Moreover, these works enable students to work together in a real- world environment by collaborating on a task (Baş, 2011). Each individual or group starts to investigate the information about the particular topic. Thus, students offer a suggestion to solve the problem; this suggestion is named as 'Project Plan' in the school. Then, each individual or group collects necessary information and document to prove or support his/her topic. They conduct experiments, make observation, collect and interpret data and record the results. At the end, each group writes a report and presents their studies in the classroom. Presented projects are discussed and evaluated by whole students and the teacher (Frank \& Barzilai, 2004; Herron, Magomo \& Gossard, 2008; Solomon, 2003; Thomas, 2000; Wolk, 2001).

Students must obey some rules while conducting project work. First, they have to define the borders of the study clearly. Second, each group member has to take responsibility in 
the study. Third, the duration of the study should be determined correctly. Finally, the applicability of the project plan should be considered (Korkmaz \& Kaptan, 2001).

As mentioned above, although PBL has some advantages in students' meaningful learning, it has certain disadvantages on this issue (Korkmaz \& Kaptan, 2002; Thomas, 2000). For instance, unless the borders of the study are well defined, meaningful learning does not occur. Moreover, students might spend a lot of time for learning. In addition, if students do not make a plan effectively, they might increase their load.

Although there have been some disadvantages on the application of PBL in science classrooms, as mentioned before, the studies investigating the effects of PBL on science achievement are increasing. Based on the literature review, there can be seen many studies investigating the effect of PBL on science achievement (Araz \& Sungur, 2007; Ayan, 2012; Filippatou \& Kaldi, 2010; Lee \& Tsai, 2004; Frank \& Barzilai, 2004; Yalçın, Turgut \& Büyükkasap, 2009). Ayan (2012) found that there was no significant difference between the achievement test post-test scores of experiment and control groups in the unit of light at fifth grade level. However, Yalçın, Turgut and Büyükkasap (2009) found that there was a significant difference between the electric unit post-test scores of control and experimental groups in the favor of experimental group.

Although there have been considerable research studies investigating the effectiveness of PBL on science achievement, there are limited studies investigating the effectiveness of PBL on chemistry concepts such as particulate nature of matter (e.g. Barak, \& Dori, 2005). Therefore, this study will provide a valuable contribution to the chemistry education literature in terms of the application of PBL on chemistry concept. Furthermore, the present study is very important for three reasons. First; it aims to determine the positive and negative conditions during the application of PBL on the structure and properties of matter. Second, it aims to provide an active participation of students and promote meaningful and long-lasting learning of students on this topic. Third, students fail to transfer their learning to daily life in science. Therefore, in this study, it is aimed to make a contribution to students' academic achievement by improving students higher order skills such as critical thinking, planning, problem solving and creativity. In the light of all these reasons, the research question of the study is presented as follows:

"What is the effect of PBL as compared to traditional instruction on seventh grade students' academic achievement in the structure and properties of matter?"

\section{METHOD}

The present study examined the effect of an independent variable (Teaching method) on a dependent variable (Academic achievement). Thus, quasi-experimental design, which is one of the quantitative research methods, was used to test the effect of PBL.

\section{Population and Sample}

In this study, accessible population was the seventh grade students in Incesu which is one of the provinces in Kayseri. In order to be able to make the generalization, number of seventh grade students in accessible population was searched and 392 seventh grade 
students were determined in this province. Sample was chosen according to convenience sampling approach since the random assignment of participants into the groups cannot execute in the quasi- experimental design. Hence, previously formed groups were assigned as a control and experimental group (Fraenkel \& Wallen, 1996). Moreover, $10 \%$ of accessible population (39.2) was considered in order to ensure external validity and at least 40 students was tried to be included in the present study. However, the region was the rural and some students could not continue due to unfavorable weather conditions. Thus, the sample of the present study was composed of 38 students in a secondary school. Eighteen of them were in the experimental group and twenty of them were in the control group. Samples were assigned randomly to these groups. Students' of 2014-2015 first-term science grades were considered while forming the groups. Although the averages are close to each other, the class whose average science grade is higher was defined as control group and the other class was assigned as the experimental group.

All students were in the age range of 13-14. Ten of the 18 students in the experimental group were female and eight of them were male. In the same way, in the control group, eight of 20 students were male and 12 of them were female. Therefore, numbers, gender and science grades of the students were considered to ensure the equalization of the groups. Also, equality of the groups was determined using the statistical analysis.

\section{Data Collection Instruments}

The Structure and Properties of Matter Achievement Test (SPMAT)

In order to form an achievement test, firstly; the objectives of the structure and properties of matter unit were determined. Then, literature was reviewed to measure each objective and question pool was created (Aslan, 2010; Kabapınar \& Adik, 2005; Onwu \& Randall, 2006; Ürek \& Tarhan, 2005). After then, 26 questions were determined from this pool to measure the objectives. After determining questions of the SPMAT, two science educators examined the questions to ensure the content validity.

To conduct the pilot study, the SPMAT was administered to 186 students who previously studied the structure and properties of matter unit. Item difficulty index and item discrimination index for all questions were also calculated considering the results of the pilot study. As a result, it was seen that the questions in the SPMAT were strong and distinctive (Crocker, \& Algina, 1986).

Table 1

Indexes of item difficulty and item discrimination for the questions of SPMAT

\begin{tabular}{llllll}
\hline Question & Dif. Index & Disc. Index & Question & Dif. Index & Disc. Index \\
\hline 1 & 0.77 & 0.22 & 14 & 0.36 & 0.40 \\
2 & 0.65 & 0.62 & 15 & 0.40 & 0.60 \\
3 & 0.62 & 0.64 & 16 & 0.48 & 0.80 \\
4 & 0.50 & 0.36 & 17 & 0.51 & 0.62 \\
5 & 0.51 & 0.66 & 18 & 0.52 & 0.76 \\
6 & 0.39 & 0.30 & 19 & 0.64 & 0.68 \\
\hline
\end{tabular}




\begin{tabular}{llllll}
\hline 7 & 0.53 & 0.58 & 20 & 0.53 & 0.74 \\
8 & 0.43 & 0.42 & 21 & 0.60 & 0.56 \\
9 & 0.45 & 0.34 & 22 & 0.32 & 0.40 \\
10 & 0.50 & 0.80 & 23 & 0.62 & 0.72 \\
11 & 0.54 & 0.80 & 24 & 0.57 & 0.62 \\
12 & 0.57 & 0.78 & 25 & 0.49 & 0.46 \\
13 & 0.37 & 0.46 & 26 & 0.42 & 0.44 \\
\hline
\end{tabular}

Exploratory factor analysis (EFA) was conducted to ensure the construct validity based on the results of pilot study. KMO value was calculated as .823. KMO value supports the hypothesis that sample size and acquired data was adequate for the EFA (Tabachnick, \& Fidell, 2013). Based on EFA, there were two factors in the SPMAT which are "Atomic structure" and "From atom to ion". Table 2 shows the rotated component matrix for the EFA of SPMAT.

Seventeen of the questions in the SPMAT were included under the factor of "atomic structure" and nine questions were involved in the factor of "from atom to ion". One sample question for each factor were presented as follows (Question 1 is belonging to the factor of "atomic structure", question 2 is belonging to the factor of "from atom to ion"):

1- Which of the following shapes is the representative model of Phosphorus $\left(\mathrm{P}_{15}\right)$ whose proton number is 15? (Note: Pictures are the representations of Bohr atomic model)

A.

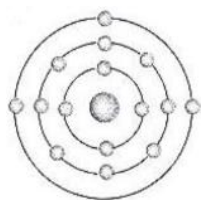

B.

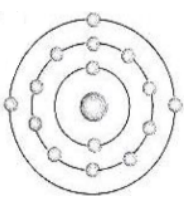

C.

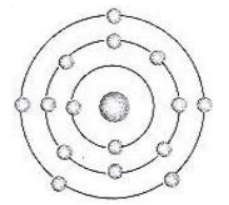

D.

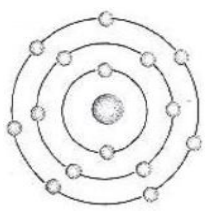

2- Proton and electron numbers of the particles K, L, M and $\mathrm{N}$ are given in the table below. According to information given, which of the particles are ions?

$\begin{array}{lll}\text { Particle } & \text { Number of protons } & \text { Number of electrons } \\ \mathrm{K} & 20 & 18 \\ \mathrm{~L} & 15 & 16 \\ \mathrm{M} & 13 & 10 \\ \mathrm{~N} & 10 & 10\end{array}$
A) $\mathrm{K}$ and L,
B) K, M and N,
C) K, L and M,
D) K, L, M and N

After the validity studies, Kuder- Richardson-20 reliability coefficient was calculated based on SPSS analysis. Table 2 indicates the reliability coefficient of SPMAT. 
Table 2

KR-20 Reliability coefficient for the SPMAT

\begin{tabular}{ccc}
\hline Alpha & Standardized item alpha & Number of items \\
\hline .849 & .853 & 26 \\
\hline
\end{tabular}

As can be seen from Table 2, KR-20 value of the SPMAT was calculated as .853. KR20 value is accepted as reliable if it is .70 and above (Tabachnick, \& Fidell, 2013). As a result, the scores of students on the SPMAT can be considered as reliable.

\section{Lesson Plans}

In order to form the lesson plans based on PBL and traditional instruction, a literature review was conducted (e.g. Filippatou \& Kaldi, 2010; Frank \& Barzilai, 2004). All objectives were placed on these lesson plans to ensure the equality. Lesson plan based on PBL included seven steps. These were the determination of the topics, organization of the groups, planning the project, application of the project, planning the presentation, making the presentation, and the evaluation. Sample lesson plan based on PBL considering the first step was presented as follows:

After completing the course; students would be able to define the atoms as bounded atoms if they were touching each other, would infer that atoms are composed of smaller particles based on the electrification event, and would show the atomic nucleus, basic particles of the nucleus and the electrons on a representative model.

In the first two course hours, following the two activities were conducted in the classroom by the students with the help of the teacher. Then, students argued about their own projects. Later, in the self-evaluation part, some questions were given to the students as a hand-out. In the same way, students were given another hand out for the 'let's Check Our Mind' activity to draw the atomic model in their mind (After the activities, draw the atomic model in your mind on the papers given).

The objective of the first activity was that students would be able to infer that atoms are composed of smaller particles based on electrification event. The apparatus of this activity were plastic pen, wool, balloon, and a piece of paper. In the process of this activity, students cut the paper into little pieces, rubbed the pen, the balloon and the wool, and brought pen and balloon closer to the paper pieces.

The objective of the second activity was that student would be able to show the atomic nucleus, basic particles of the nucleus, and the electrons on a representative model. The apparatus of this activity were 11 pieces of green ball, 11 pieces of red ball, 11 pieces of yellow ball, one big bowl and one orange. In this activity, firstly, students formed the groups consisting of four or five students. Secondly, they put the yellow and red balls into the bowl. Thirdly, they formed a cycle around the bowl with the green balls. Fourthly, they drew the shape on their notebooks. (Activity was conducted as a group but the drawings were done by all the students). Fifthly, they peeled the orange as a whole and finally, examined the shape and drew the shape on their notebooks. 
At the end of the activities, students executed self- evaluation. They also discussed with each other and their teacher. They discussed what they observed during the first activity and explained their ideas on why the pen and the balloon attracted the paper pieces. They also discussed the force keeping the pen and the paper pieces together and atoms were held by such a force. They also discussed the answers of the questions "What do the materials in the second activity represent?" and "Do you think there is a relation between the forces keeping the balloon and the pen with the paper pieces and the force keeping the particles of an atom together?"

\section{Classroom Observation Checklist}

Treatment process in the present study was executed by one of the researchers since this researcher was the teacher of the students in these groups. In order to minimize this implementation threat to internal validity, observations were carried out throughout the study. Hence, treatment verification was provided.

An observation checklist was used to eliminate the treat that may cause due to the bias of the researcher. A science teacher from another secondary school observed the classes for four weeks in each group and evaluated the researcher according to the observation checklist. The observation checklist used in the present study was taken from the study of Bektaş and Taber (2009). There were 21 items in this observation checklist and eight of them were mutual for the PBL and traditional instruction based on regular science curriculum (e.g. Do students can ask questions during the lesson?), nine of them aim to measure the characteristic of PBL (e.g. Could students discuss with each other about the course?), and four of them measure the characteristics of traditional instruction based on regular science curriculum (e.g. Does students take notes during the instruction?). There were three alternatives (nothing, sometimes, and always) in the observation checklist.

\section{Data Collection Process}

1. Literature review was conducted related to independent and dependent variables.

2. Course objectives were examined and determined.

3. An achievement test was developed considering the test development steps.

4. Pilot study was executed to develop a valid and reliable test

5. Lesson plans based on PBL and traditional instruction were prepared

6. Sample of the study were determined in a public school.

7. Duration of the main study was six weeks. Firstly, SPMAT was administered to the groups as a pre-test in the first week by one of the researchers on the same day.

8. Whilst PBL activities were implemented in the experimental group, the traditional instruction proposed by the regular program was performed in the control group. Treatment of the study was lasted for four weeks in two groups. There were four hour science lessons in each week. In other words, the classroom instruction of the groups was four 45-minute session per week. During the treatment, prepared lesson plans were considered in each group. The science concepts related to the structure and properties of matter was covered as a part of the regular classroom curriculum in the science course. In the experimental group, in the first two hours of each week, the teacher introduced the topic of the related week and the sample projects. In the rest two 
hours of each week, students were assigned to prepare projects related to each week's objectives. On the other hand, in the control group, the prepared lesson plan based on the regular science curriculum was followed by the teacher for four weeks.

9. Classroom observation checklist was used to ensure treatment verification

10. At the end of the study, SPMAT was administered as a post-test in the sixth week

\section{Data Analysis}

Descriptive statistics and inferential statistics were used to analyse the data of the SPMAT by using SPSS-20 package program. Normality assumption was controlled by using descriptive statistics. As for inferential statistics, independent samples t-test was used to check if the groups are equal or not in terms of their achievement in SPMAT in the beginning of the study. This test was also employed at the end of the study to see whether there was a significant difference between groups in terms of achievement in SPMAT or not.

Observation checklist was used in order to understand whether the teaching methods in both groups were implemented properly. The observer' results on this checklist were analysed statistically (Nothing $=1$ point, sometimes $=2$ points, and always $=3$ points). To control if the PBL was employed appropriately, the points taken from 17 items in the checklist were calculated. If the scores were between 34 and 51, then lessons in the experimental group were considered to be appropriate to the PBL steps. On the other hand, to decide whether regular science curriculum was applied properly or not, the total points taken from 12 items in the observation checklist was calculated and if the results were between 24 and 36, then lessons were considered as traditional.

\section{FINDINGS}

\section{Results Belong to Descriptive Statistics on SPMAT Scores}

In order to understand whether the data obtained from SPMAT showed a normal distribution or not, descriptive statistical analysis was conducted. To understand the scores of SPMAT distribute normally, firstly the mean, median, and mode values were controlled in terms of the equality. Then, skewness and kurtosis values were controlled. The skewness and kurtosis values should not be less than "-2" or more than " +2 ". As seen in Table 3, the scores of SPMAT for both the pre-test and the post-test distributed normally and it was decided that data belonging to the achievement test showed a normal distribution (Field, 2013; Pallant, 2013). As it can be concluded based on the descriptive statistic results, inferential statistical analysis can be used for this study.

Table 3

Descriptive statistics for the pre-SPMAT and post-SPMAT

\begin{tabular}{lllllll}
\hline & \multicolumn{2}{c}{ Experimental Group } & \multicolumn{2}{c}{ Control Group } & \multicolumn{2}{c}{ Total } \\
\hline SPMAT & Pre-test & Post-test & Pre-test & Post-test & Pre-test & Post-test \\
\hline Number of students & 18 & 18 & 20 & 20 & 38 & 38 \\
Missing value & 0 & 0 & 0 & 0 & 0 & 0 \\
Mean & 7.33 & 16.00 & 6.55 & 14.25 & 6.92 & 15.07 \\
Median & 8.00 & 16.00 & 6.00 & 14.00 & 7.00 & 14.00 \\
Mode & 8.00 & 17.00 & 5.00 & 14.00 & 8.00 & 14.00 \\
Skewness & -.779 & -.072 & .210 & .741 & -.226 & .328 \\
Kurtosis & .961 & -.722 & -.010 & .698 & -.169 & -.297 \\
\hline
\end{tabular}




\section{Results Belong to Inferential Statistics on SPMAT Scores}

Comparison of the Pre-SPMAT Scores of Experimental and Control Groups

Table 4

Independent sample t-test results of both groups for the Pre-SPMAT

\begin{tabular}{llllll}
\hline \multirow{2}{*}{ Equal Variances } & \multicolumn{3}{c}{ Levene's Test } & \multicolumn{2}{c}{ t-test } \\
\cline { 2 - 6 } & F & Sig. & df & Sig. (2-tailed) \\
\hline \multirow{2}{*}{ Pre-SPMAT } & Assumed & .430 & .516 & 36 & .265 \\
& Not assumed & & & 35.920 & .263 \\
\hline
\end{tabular}

As can be seen from Table 4, Levene's test was not significant for the Pre-SPMAT. Thus, variances of scores for the groups were accepted as equal. There was no significant mean difference ( $t(36)=1.13, p>.05$ ) between the experimental and control groups in terms of the pre-test scores of "structure and properties of matter" (SPM). In other words, groups were equal with respect to their academic achievement on the SPM at the beginning of the research. According to this result, there was no need to use the Pre-SPMAT scores as a covariate after the treatment in order to control pre-existing differences.

Comparison of the Post-SPMAT Scores of Experimental and Control Groups

Table 5

Independent sample t-test results of both groups for the post-SPMAT

\begin{tabular}{lllllll}
\hline & & \multicolumn{3}{c}{ Levene's Test } & \multicolumn{2}{c}{ t-test } \\
\cline { 3 - 6 } & Equal Variances & F & Sig. & df & Sig. (2-tailed) \\
& Assumed & .00 & .986 & 36 & .270 \\
Post-SPMAT & Not assumed & & & 36.00 & .268 \\
\hline
\end{tabular}

As can be seen from Table 5, Levene's test was not significant for the post-SPMAT scores (.986>.05). Therefore, variances of scores for the groups were accepted as equal. Since the variances are accepted as equal, sig2 value (Assumed) was taken into account. When this value (.270) was considered, there was no significant difference between the achievement post-scores of experimental and control groups. Hence, Null hypothesis was accepted. This result could be generalized to the sample since there was no practical significance when considering power of the study and the effect size.

\section{Results of the Classroom Observation Checklist}

All scores marked by observer on the observation checklist were between 34 and 51 . Thus, the lessons in the experimental group were considered to be appropriate for the PBL steps. In a similar vein, observer gave the scores between 24 and 36 for the control group observations. Hence, the lessons in the control group were considered to be appropriate for the traditional instruction based on regular science curriculum. 


\section{DISCUSSION and CONCLUSIONS}

The present study states that there is no significant effect between the post-test mean scores of seventh grade students exposed to PBL and those exposed to traditional instruction on the population means of the structure and properties of matter achievement post-test scores. Although, the mean score of experimental group is higher than the mean score of the control group (see Table 3), it is seen that this difference between the mean scores is not significant (see Table 5). This result shows similarities with certain studies in the literature (e.g. Bağc1, 2005). On the other hand; Doppelt (2003), Filippatou and Kaldi, (2010), and Green (1998), showed PBL increases students' academic achievement on behalf of the experimental group. The conflict between these studies and the present study may be caused by following reasons;

Students, who are used to traditional instruction based on national curriculum, may have adaptation problems towards PBL in the present study. It is known that students who are familiar to the teacher centred instruction may have difficulty in the project works. Moreover, PBL may not be an effective learning strategy for students who have some challenges in learning and have inadequate skills in writing and reading (Thomas, 2000; Westwood, 2006). Also, the central teaching strategy of PBL is the project. Therefore, students have to learn concepts of the matter via the project (Thomas, 2000). However, students did not be successful in learning of this topic via the project. Moreover, Thomas (2000) states that PBL projects are the curriculum. Hence, the projects works cannot serve to provide illustrations, examples, and practical applications for the concepts taught since students would have made the traditional instruction.

In the present study, some students could not show their real academic performance due to the disagreement of group members. Similarly, Achilles and Hoover (1996) stated that students failed to work together well in their study. Researchers attribute this failure to students' lack of social skills. Hawthorne effect which is one of the threats to internal validity states that students in the control groups may perform more poorly than students in the experimental groups because of the demoralization (Fraenkel \& Wallen, 1996). However, in the present study, since students in the experimental group did not know about the application of different instruction, they may not perform better because of the novelty of the treatment and they have demoralized because of the disagreement among group members. Students in the control groups did not have any demoralization.

A third reason may be the fear of students in the experimental group toward PBL. These students were observed to be scared. As Başaran (2005) states, the fear of failure in a duty may affect learning and academic achievement negatively.

Fourth reason is that the topic of the structure and properties of matter may not draw students' attention. Forcing students to study for this topic might decrease their academic achievement. Moreover, the project was the exercise for students, not the PBL project. They did not construct and transform their knowledge about this topic using their problem-solving skills (Bereiter, \& Scardamalia, 1999). According to Alozie, Moje, \& Krajcik (2010), in these types of studies, students should be directed towards their interest and abilities. This is the limitation of the present study. 
Fifth reason is that students could not fulfil all objectives of the course during the project works or their presentation. Krajcik, Blumenfeld, Marx, Bass, Fredricks, and Soloway (1998) states that teachers can help students in examining the scientific worth of their objectives, the benefits of their objectives. Even though, researchers prepared the activities covering all objectives and introduced before the project works, they missed some objectives while they were preparing their own projects. On the other hand, all objectives were covered by the teacher in the control group.

Sixth reason is that students were in a rural environment where there was no enough necessary research sources and equipment. PBL requires students to make a deep research and yield a product (Helm \& Katz, 2011). In other words, technology has a powerful affect in promoting student learning while doing project and presenting it (Blumenfeld et al. 1991). The use of PBL in class is possible after providing the information that is needed for the project (Baş, 2011). Therefore, being lack of necessary technical support affected students' performance negatively. Similarly, in their study, Edelson, Gordon, and Pea (1999) reported that students were sometimes not able to access the technology necessary to conduct the investigation. In order to overcome this treat, researchers tried to supply resources, internet access, and material, but it was not enough for all students.

Seventh reason is the communication problem. Since the present study was conducted in a rural school, members of a group who live in different locations had difficulties in communication. Therefore, these students could not come together and work for a project together. To overcome this problem, students shared their topics, searched, and combined their learning. Therefore, they could not comprehend their topics because each member focused on his/her own topic.

Eighth reason can be the time issue. The whole study lasted in four weeks and students were asked to prepare a project related to the objectives of each week. However, students did not adhere to their time schedule and had difficulty in reaching to the resources. Thomas (2000) states that if students do not make a plan effectively in their studies, they might spend a lot of time for learning and they might increase their load. Therefore, Marx, Blumenfeld, Krajcik, \& Soloway (1997) emphasized that teachers have a key role to enable students to use time effectively since projects often take longer than anticipated.

Ninth reason is that the students in the experimental group regarded their projects as assignments or performance tasks given in other courses. If students do not give an importance to the project works, they should be unsuccessful in their lessons (Çiftçi, 2010). In the present study, students were asked to prepare the project and they were informed about how to prepare these projects. However, some students tended to prepare their projects as they do their assignments or homework. Therefore, this decreased their academic achievement.

Lastly, the difference between the mean scores is not significant since "John Henry effect" may cause the achievement of the control group students. During the study, control group students learned that they are compared with other group and they over 
performed to reach the experimental group students. Although teacher did not any effect on this issue, interaction between the groups could not be prevented since students were living in a small village and they knew each other.

As a conclusion, this study contributes to the implementation of PBL when considered the above reasons. The implementation of the teaching methods has a crucial role in science education. Hence, this study contributes to the science teachers to instruct the effective constructivist teaching strategies and promote meaningful learning on students.

\section{SUGGESTIONS}

It was seen that it is not easy to implement PBL. Therefore, pre-activities should be performed for the adaptation of students and teachers before treatment. This is the limitation of the present study. Treatment process in the present study was executed by one of the researchers, but teachers, not researcher, should conduct the study to eliminate the bias and overcome the implementation threat. The adaptation of students is important issue since the students perceived the project work as a workload and their achievement toward course were affected negatively. To overcome this issue, students should be given simple project works throughout the semester. Moreover, in order to increase students' motivation, prepared project works should be presented in a science exhibition. Time issue is one of the most important concerns in PBL activities. In this study, treatment lasted for four weeks. Therefore, PBL activities were not implemented sufficiently in terms of time limitation. In order to be able to use the time most efficiently, there should be well-prepared time schedule for students and also teachers should give feedback on time to the groups for their project works.

The present study was conducted using quantitative research method. Hence, an action research which is one of the qualitative research methods should be conducted to promote understanding of students in science concepts using PBL. Non-random assignment of the participant to the groups may cause differences in variances and this situation may affect the results. Random assignment of the participants into the groups did not execute in the present study. Thus, an experimental study should be conducted using random assignment to control subject characteristics and to enhance internal validity. This study is limited with the unit of structure and properties of matter on seventh grade. Different studies on different topics in different grade level should be conducted. The effect of PBL combined with different teaching methods on academic achievement should also be studied.

In order to increase the potential of PBL, projects should be designed that promote student motivation and metacognitive thinking skill. Teachers should also be supported in creating PBL. Moreover, in-service training should be given to the teachers based on PBL. In the education faculties, PBL should be emphasized effectively. 


\section{REFERENCES}

Achilles, C. M., \& Hoover, S. P. (1996). Exploring problem-based learning (PBL) in grades 6-12. Paper presented at the Annual Meeting of the Mid-South Educational Research Association, Tuscaloosa, AL. (ED 406 406).

Alozie, N. M., Moje, E. B., \& Krajcik, J. S. (2010). An analysis of the supports and constraints for scientific discussion in high school project-based science. Science Education, 94(3), 395-427.

Aslan, S. (2010). The effect of argument based teaching approach on conceptual perception of students. Kastamonu Education Journal, 18(2), 467- 500

Ayan, M. (2012). Proje tabanlı öğrenme yaklaşımının ilköğretim öğrencilerinin fen bilgisi dersi akademik başarı düzeyine etkisi. Journal of Turkish Educational Sciences, 10(1), 167-183

Araz, G. \& Sungur, S. (2007). Effectiveness of problem-based learning on academic performance in genetics. Biochemistry and Molecular Biology Education, 35(6), 448451.

Bağc1, U. (2005). Illköğretim fen bilgisi öğretiminde uygulanan proje tabanlı öğrenme yönteminin ögrrencilerin başarı düzeylerine etkisi. Unpublished master thesis, Selçuk University, Graduate School of Educational Sciences. Konya, Turkey.

Barak, M., \& Dori, Y. J. (2005). Enhancing undergraduate students' chemistry understanding through project-based learning in an IT environment. Science Education, 89(1), 117-139.

Baran, M. \& Maskan, A. (2010). The effect of project-based learning on pre-service physics teachers'electrostatic achievements. Cypriot Journal of Educational Sciences, 5, 243-257.

Baş, G. (2011). Investigating the effects of project-based learning on students' academic achievement and attitudes towards English lesson. TOJNED: The Online Journal of New Horizons in Education, 1(4), 1-15.

Başaran, İ. E. (2005). Ĕgitim psikolojisi (gelişim, öğrenme ve ortam). Ankara: Nobel Yayın Dağıtım, Turkey.

Bektaş, O., \& Taber, K.S. (2009). Can science pedagogy in English schools inform educational reform in Turkey? Journal of Turkish Science Education, 6(3), 66-80

Bell, S. (2010). Project-based learning for the 21st century: Skills for the future. The Clearing House, 83(2), 39-43

Bereiter, C. \& Scardamalia, M. (1999). Process and product in PBL research. Toronto: Ontario Institutes for Studies in Education/University of Toronto. 
Blumenfeld, P. C., Soloway, E., Marx, R. W., Krajcik, J. S., Guzdial, M., \& Palincsar, A. (1991). Motivating project-based learning: Sustaining the doing, supporting the learning. Educational psychologist, 26(3-4), 369-398

Cavallo, A.M.L., McNeely, J.C., \& Marek, E.A. (2003). Eliciting students' understandings of chemical reactions using two forms of essay questions during a learning cycle. International Journal of Science Education, 25(5), 583-603

Crocker, L. \& Algina, J. (1986). Introduction to classical and modern test theory. Florida: Rinehart and Winston

Çiftçi, S. (2010). The opinions of the teachers in upper primary classes concerning the student performance tasks. Elementary Education Online, 9(3). 934-95

Doppelt, Y. (2003). Implementation and assessment of project-based learning in a flexible environment. International Journal of Technology and Design Education, 13, $255-272$

Edelson, D. C., Gordon, D. N, \& Pea, R. D. (1999). Addressing the challenge of inquiry based learning. Journal of the Learning Sciences, 8, 392-450.

Field, A. (2013). Discovering statistics using SPSS. 4th ed. London: Sage

Filippatou, D. \& Kaldi, S. (2010). The effectiveness of project-based learning on pupils with learning difficulties regarding academic performance, group work and motivation. International Journal of Special Education, 25(1), 17-26

Fraenkel, J. K, \& Wallen, N. E. (1996). How to design and evaluate research in education (third edition). New York: McGraw-Hill, Inc

Frank, M. \& Barzilai, A. (2004). Integrating alternative assessment in a project-based learning course for pre-service science and technology teachers. Assessment \& Evaluation in Higher Education, 29(1), 41-61

Green, A. (1998). Project based learning: moving students through the GED with meaningful learning, General Educational Development Tests, Texas

Harris, J. (2002). Activity design assessments: an uncharacteristic consensus. Learning and Leading with Technology, 27(7), 42-50

Helm, J. H., \& Katz, L. G. (2011). Young investigators: The project approach in the early years. Teachers College Press

Herron, S., Magomo, D., \& Gossard, P. (2008). The wheel garden: Project-based learning for cross curriculum education. International Journal of Social Sciences, 3(1), 44-53

Kabapınar, F. M., \& Adik, B. (2005). Secondary students' understanding of the relationship between physical change and chemical bonding. Ankara University, Journal of Faculty of Educational Sciences, 38(1), 123-147. 
Korkmaz H. \& Kaptan, F. (2001). Project based learning in science education. Hacettepe University Journal of Education, 20, 193-200

Korkmaz, H. \& Kaptan, F. (2002). The effects of project-based learning on elementary school students' academic achievement, academic self-concepts and study time in science education. Hacettepe University Journal of Education, 22, 91-97

Krajcik, J. S., Blumenfeld, P. C., Marx, R. W., Bass, K. M., Fredricks, J., \& Soloway, E. (1998). Inquiry in project-based science classrooms: Initial attempts by middle school students. The Journal of the Learning Sciences, 7, 313-350.

Krajcik, J. S., Blumenfeld, P. C., Marx, R. W., \& Soloway, E. (1994). A collaborative model for helping middle grade science teachers learn project-based instruction. The Elementary School Journal, 94, 483-497

Lee, C. L., \& Tsai, F. Y. (2004). Internet project based learning environment. Journal of Computer Assisted Learning, 20, 31-39

Liang, L. L. \& Gabel, D. L. (2005). Effectiveness of a constructivist approach to science instruction for prospective elementary teachers. International Journal of Science Education, 27(10), 1143-1162

Marx, R. W., Blumenfeld, P. C., Krajcik, J.S., \& Soloway, E. (1997). Enacting projectbased science: Challenges for practice and policy. Elementary School Journal, 97, 341358.

Matthews, M. R. (1993). Constructivism and science education: Some epistemological problems, Journal of Science Education and Technology, (2)1, 359-370

McGrath, D. (2002). Getting started with project-based learning. Learning and Leading with Technology, 30(3), 42-50.

Onwu, G.O.M., \& Randall, E. (2006). Some aspects of students' understanding of a representational model of the particulate nature of matter in chemistry in three different countries. Chemistry Education Research and Practice, 7(4), 226-239.

Pallant, J. (2013). SPSS survival manual. 5th ed. Buckingham: Open University Press.

Preuss, D. A. (2002). Creating a project-based curriculum. Tech Directions, 62(3), 1619.

Solomon, G. (2003). Project-based learning: a primer, Technology and Learning, 23(6), 20-30.

Tabachnick, B. G., \& Fidell, L. S. (2013). Using Multivariate Statistics (6th ed.) Boston, USA: Pearson.

Taber, K. S. (2008). Exploring student learning from a constructivist perspective in diverse educational contexts. Journal of Turkish Science Education, 5(1), 2-21

Thomas, J. W. (2000). A review of research on project based learning, Retrieved from http://www.k12reform.org/foundation/pbl/research (last accessed 30/08/2015). 
Ürek, R. Ö., \& Tarhan, L. (2005). An active learning application based on constructivism to remedy misconceptions on covalent bonding. Hacettepe University Journal of Education, 28, 168-177.

Westwood, P. (2006). Teaching and learning difficulties: cross-curricular perspectives, Camberwell, Vic: ACER. Press

Winn, S. (1997). Learning by doing: teaching research methods through student participation in a commissioned, Studies in Higher Education, 20(2), 203-214.

Wolk, S. (2001). The benefits of exploratory time. Educational Leadership, 59(2), 5659.

Yalçın, S. A., Turgut, Ü. \& Büyükkasap, E. (2009). The effect of project based learning on science undergraduates' learning of electricity, attitude towards physics and scientific process skills. International Online Journal of Educational Science, 1(1), 81-105.

\section{Turkish Abstract}

\section{Proje Tabanli Öğrenmenin 7. Sınıf Öğrencilerinin Akademik Başarılarına Etkisi}

$\mathrm{Bu}$ çalışmanın amacı 7. sınıf öğrencilerinin proje tabanlı öğrenmenin maddenin yapısı ve özellikleri konusundaki akademik başarılarına bir etkisinin olup olmadığını incelemektir. Çalışmada 7. sınıf öğrencilerinin akademik başarılarını geleneksel yöntemlerin ve proje tabanlı öğrenme yönteminin etkilerini ölçmek için karakteristik nicel araştırma yöntemlerine göre ön testson test kontrol grubu, yarı deneysel desen kullanılmıştır. Çalışmada uygun örnekleme yöntemi tercih edilmiş ve 38 öğrenci kullanılmıştır. Veri toplama aracı olarak maddenin yapısı ve özellikleri başarı testi, ders planı ve gözlem kontrol listesi kullanılmıştır. Maddenin yapısı ve özellikleri başarı testinden elde edilen verileri analiz etmek için bağımsız gruplar t-testi kullanılmıştır. Elde edilen sonuçlara göre başarı testi uygulanan deney ve kontrol gruplarının performansları arasında anlamlı bir farklılık olmadığı saptanmıştır. Öğretmen ve öğrencinin derse adaptastonunu sağlamak için proje tabanlı öğrenmeye dayalı yöntem için ders öncesi hazırlık yapılması gerektiği alanyazında tartışılmış ve öneriler bölümünde belirtilmiştir.

Anahtar Kelimeler: fen bilgisi eğitimi, proje tabanlı öğrenme, akademik başarı, maddenin tanecikli yapısı, yarı deneysel desen

\section{French Abstract}

L'Effet de Projet Apprentissage Basé sur l'Accomplissement Universitaire d'Étudiants de Cinquième

Le but de cette étude est d'examiner s'il y a un effet significatif de projet l'approche d'apprentissage basée sur les étudiants de septième année l'accomplissement universitaire dans la structure et les propriétés de matière. Dans l'étude, selon les caractéristiques de méthodes de recherche quantitatives, pretest-posttest le groupe témoin la conception quasi-expérimentale a été utilisée pour tester l'effet d'apprentissage à base de projet et des méthodes traditionnelles sur l'accomplissement universitaire des étudiants de septième année. L'échantillonnage de commodité a été préféré et 38 étudiants ont participé à cette étude. La structure et les propriétés de test d'accomplissement de matière, des plans de leçon et la liste de contrôle d'observation ont été 
utilisées comme l'instrument de collecte de données. Pour analyser les données obtenues de la structure et des propriétés de test d'accomplissement de matière, le t-test d'échantillons indépendant a été exécuté. Basé sur les résultats, il n'y a aucune différence significative entre le grand nombre des groupes témoins et expérimentaux qui est obtenu de leur "le test d'Accomplissement" la performance post-de-test. Les discussions basées sur la littérature ont été effectuées et les suggestions ont été exécutées comme des pré activités basées sur le projet l'apprentissage basé devrait être exécuté pour l'adaptation d'étudiants et des professeurs avant le traitement.

Mots Clés: enseignement des sciences, projet apprentissage basé, accomplissement universitaire, nature de particule de matière, design(conception) expérimental quasi

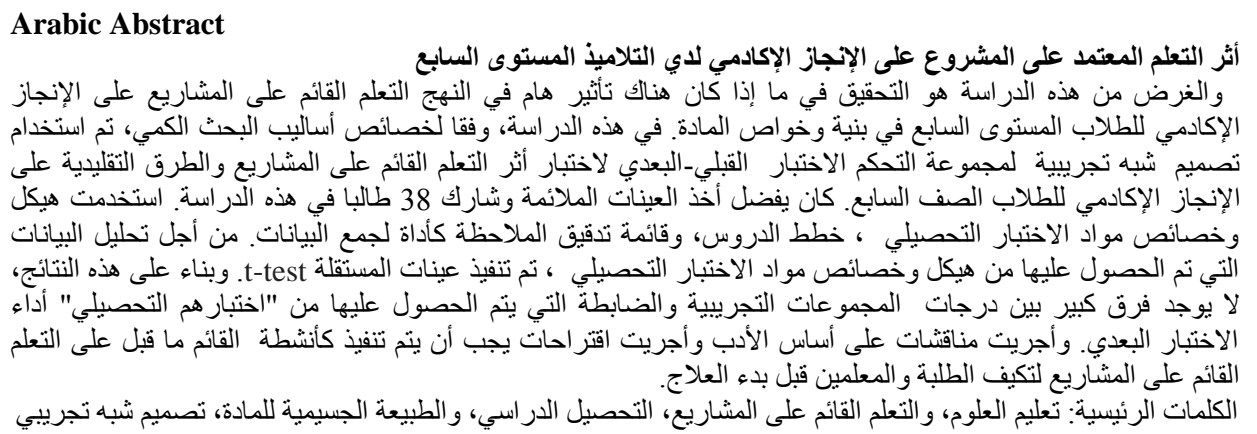

\section{German Abstract}

Die Wirkung des projektbasierten Lernens auf die akademische Leistung der Schüler der 7. Klasse

Der Zweck dieser Studie ist es, zu untersuchen, ob es einen signifikanten Effekt der Projektbasierten Lernansatz auf siebten Klasse Studenten akademische Leistung in der Struktur und Eigenschaften der Materie. In der Studie wurde nach den Merkmalen der quantitativen Forschungsmethoden, Pretest - Posttest-Kontrollgruppe quasi-experimentelles Design verwendet, um die Wirkung von projektbasiertem Lernen und traditionellen Methoden auf siebte Klasse Studenten akademischen Leistung zu testen. Bequemlichkeit Stichproben wurde bevorzugt und 38 Studenten nahmen an dieser Studie. Als Datenerfassungsinstrument wurden die Struktur und die Eigenschaften von Materieleistungstest, Unterrichtsplänen und Beobachtungs-Checkliste verwendet. Um die aus der Struktur und den Eigenschaften des Materie-Ergebnistests erhaltenen Daten zu analysieren, wurde ein unabhängiger Proben-t-Test durchgeführt. Basierend auf den Ergebnissen gibt es keinen signifikanten Unterschied zwischen den Scores der experimentellen und Kontrollgruppen, die aus ihrer "Leistungstest" -Post-Test-Leistung erhalten werden. Diskussionen auf der Grundlage von Literatur wurden durchgeführt und Vorschläge wurden als Voraktivitäten auf der Grundlage von projektbasiertem Lernen durchgeführt werden für die Anpassung der Schüler und Lehrer vor der Behandlung durchgeführt werden.

Schlüsselwörter: wissenschaftserziehung, projektbezogenes lernen, akademische leistung, partikuläre natur der materie, quasi experimentelles design 


\section{Malaysian Abstract}

Kesan Pembelajaran Berasaskan Projek ke atas Pencapaian Akademik Pelajar Gred Tujuh

Tujuan kajian ini adalah untuk menyiasat sama ada terdapat kesan yang ketara pendekatan pembelajaran projek berdasarkan pencapaian akademik pelajar gred ke tujuh dalam struktur dan sifat-sifat jirim. Dalam kajian itu, mengikut ciri-ciri kaedah penyelidikan kuantitatif, kumpulan kawalan ujian pra-pasca reka bentuk kuasi-eksperimen telah digunakan untuk menguji kesan pembelajaran berasaskan projek dan kaedah tradisional ke atas pencapaian akademik pelajar gred ketujuh. Persampelan mudah telah dipilih dan 38 pelajar telah mengambil bahagian dalam kajian ini. Ujian pencapaian struktur, rancangan pelajaran, dan senarai semak pemerhatian telah digunakan sebagai instrumen pengumpulan data. Dalam usaha untuk menganalisis data yang diperoleh daripada ujian pencapaian struktur, sampel bebas ujian-t dilakukan. Berdasarkan keputusan, tidak ada perbezaan yang signifikan antara skor kumpulan eksperimen dan kawalan yang diperoleh daripada "ujian Pencapaian" Prestasi pasca ujian mereka. Perbincangan berdasarkan kesusasteraan telah dijalankan dan cadangan telah dilakukan sebagai pra-aktiviti berasaskan pembelajaran berasaskan projek harus dilakukan untuk penyesuaian pelajar dan guruguru sebelum rawatan.

Kata Kunci: pendidikan sains, pembelajaran berasaskan projek, pencapaian akademik, zarah sifat benda, reka bentuk kuasi eksperimen

\section{Russian Abstract \\ Влияние Обучения на Проектной Основе на Академическый Успех Седьмого Класса Учеников}

Целью данного исследования является ли эффективным обучение струтуре и свойствам материи учеников 7-го класса на проектной основе, повысит ли это их успеваемость. В исследовании в соответствии с характеристикой количественных методов исследования, предтестовая-посттестовых контрольная группа квазиэкспериментальной конструкция была использована для проверни эффекта проекта, основанного на изучениеи традиционных методов по успеваемости учащихся седьмого класса. 38 студентов приняли участие в этом исследовании. Структура и свойства материи достижение тест, планы уроков и наблюдения контрольного списка были использованы в качестве инструментов для сбора данных. Чтобы получить из данных структур и о свойства материи независимых выборок анализ был проведен т-тест. Результаты показывают, что нет существенной разницы между экспериментальными и контрольными группами счета, которая получается из “Теста Успеха". Дискуссии основанные на литературы были проведены и предложения были выполнены как заранее активирован, основанные на учебный проект должен быть выполнила для адаптации студентов и преподавателей до лечения.

Ключевые Слова: естественные науки, обучение на основе проектов, академические успехи, сажевая природа материи, квазиэкспериментальний дизайн 